\title{
Compost Tea and Poultry Litter Extract: Alternative Organic Management Approaches for Stem Canker of Potato Caused by Rhizoctonia solani
}

\author{
Md. Rashidul Islam ${ }^{1}$, Chhoa Mondal ${ }^{1}$, Ismail Hossain ${ }^{1} \&$ M. Bahadur Meah ${ }^{1}$ \\ ${ }^{1}$ Department of Plant pathology, Bangladesh Agricultural University, Mymensingh, Bangladesh \\ Correspondence: Md. Rashidul Islam, Department of Plant pathology, Bangladesh Agricultural University, \\ Mymensingh 2202, Bangladesh. E-mail: rasha740177@yahoo.com
}

Received: August 15, 2013 Accepted: August 30, 2013 Online Published: September 15, 2013

doi:10.5539/jas.v5n10p261 URL: http://dx.doi.org/10.5539/jas.v5n10p261

\begin{abstract}
An experiment was conducted in the field laboratory, Department of Plant pathology, Bangladesh Agricultural University, Mymensingh to know the efficacy of compost tea and poultry litter extract in controlling stem canker of potato under natural infection condition. Significant effect of different treatments was observed on the incidence of stem canker of potato as compared to control. The results evidently showed the lowest stem canker incidence recorded in plots when IPM Lab Biopesticde was applied followed by foliar spray of Ridomil, compost tea, and BAU-Biofungicide while the highest stem canker incidence was recorded in untreated control plot. However, the soil drenching of compost tea and poultry litter extract also performed better as compared to control in reducing the incidence of stem canker. Significant effect of the treatments was observed on the plant height and yield except number of plant raised per tuber. Foliar and soil application of compost tea, poultry litter and mustard oil cake showed better performance in increasing the plant height and yield as compared to all other treatments. Benefit cost analyses of the treatments revealed that foliar application of compost tea showed highest BCR (65.20) followed by Soil application of IPM Lab Biopesticide with BCR 54.38. The treatments viz. foliar spray of Ridomil and BAU-Biofungicide resulted 35.31 and $38.88 \mathrm{BCR}$, respectively which were the second best treatments as compared to untreated control. The results indicated that an investment of Tk. 1.00 may lead to a profit up to Tk. 65.20 by foliar application of compost tea which shows the maximum profit in the present study. Therefore, compost tea as foliar spray may be used as an alternative environment-friendly approach to control stem canker of potato along with other biological means with maximum economic return.
\end{abstract}

Keywords: alternative, organic management, stem canker, Rhizoctonia solani and potato

\section{Introduction}

Potato is one of the important vegetables in Bangladesh and has been contributing to the nutrition of poor peoples of Bangladesh who have been suffering from malnutrition. Potato has also been contributing to the recent development of Agro and Food industries in Bangladesh. However, the production of these two major vegetables in Bangladesh is far below as compared to the other growing countries of the World. The main limiting factors for production of potato and tomato in Bangladesh are the poor quality seeds, the management factors and insect-pest and diseases. Rhizoctonia stem canker of potato caused by Rhizoctonia. solani is one of the destructive diseases of potato (Bains et al., 2002) and the pathogen is widespread in all potato growing countries (Jager et al., 1996, Bains et al., 2002; EL-Bakali \& Martin, 2006). Black scurf symptoms caused by $R$. solani reduce tuber quality and marketability and cause a huge economic loss in potatoes annually (Banville, 1989; Errampalli \& Johnston, 2001). Around $30-40 \%$ yield reduction was reported in the temperate zones (Little et al., 1998) and $19.2-34 \%$ in the tropical and subtropical regions by this disease (Banville, 1989; Carling et al., 1989). The typical disease symptoms include death of pre-emerging sprouts, reddish brown to brown cankers on the underground stem parts and stolons which interrupt the starch translocation to the tubers which results in small, green, aerial tubers formation and sclerotia formation on progeny tubers. Formation of tuber-borne sclerotia downgrades tuber quality (Jager et al., 1991) with the development of malformed tubers and an alternation in target size and number of tubers (Jager et al., 1996; Carling et al., 1989). 
Stem canker is an important threat for potato production in some growing areas of Bangladesh in the recent years. However, the management of $R$. solani seems difficult due to its soil borne nature (Agrios, 2005). Although many cultural, chemical and biological approaches demonstrated to control the stem canker caused by $R$. solani, none of them are found effective. However, benefits of compost or its extract or tea has been demonstrated to reduce the disease incidence and severities in many crops. For example, suppression of Rhizoctonia in compost media has been reported by Nelson and Hoitnik (1982), Chen et al. (1988), and Tunlid et al. (1989). Composted manure suppressed damping off by Rhizoctonia solani in potting media experiments with radish seedlings (Raphanus sativus). (Voland \& Epstain, 1994). Trichoderma in addition to being a strong colonizer of compostable materials has potential to control plant diseases (Hoitnik et al., 1993) and have been reported to suppress Pythium and Rhizoctonia (Papavizas, 1985). However, Poultry litter or chicken manure compost gave better control of Phytophthora cinnamomi root-rot on Lupinus albus than cow, horse, or sheep manures. Low incidence of seedling death in chicken manure compost-amended potting mixes correlated with low population of $P$. cinnamomi, high levels of microbial activity in particular the activity of endospore-forming bacteria (Aryantha et al., 2000). Tsror et al., (2001) reported that compost amendment applied in furrow could reduce black scurf incidence in organically grown potatoes. Compost tea, in modern terminology, is a compost extract brewed with a microbial food source like: molasses under forced aeration and grows population of microbial community (Diver, 1998). Compost tea ensures diverse and healthy food web communities which provide protection of plants from disease. A modest to major control of several plant diseases were reported by the use of compost tea. In Bangladesh, farmers have no option to use compost or organic manure instead of chemical fertilizers to manage the soil and plant health because of the shortage of organic manure in the country. Therefore, using compost tea instead of solid compost application to the soil may be the best use of technology to improve crop productivity and crop heath. In the present work, the efficacy of compost tea and poultry litter extract in controlling stem canker disease of potato were evaluated as compared to chemical and other biological means.

\section{Materials and Methods}

\subsection{Experimental Site, Material, Treatments and Design}

An experiment was conducted in the field laboratory, Department of Plant pathology, Bangladesh Agricultural University, Mymensingh during October, 2011 to March, 2012. The land was firstly ploughed with a power tiller and was exposed to sunlight for at least 7 days. Then the land was ploughed and cross-ploughed until the soil had a good tilth followed by laddering to level the land and to remove and weeds and break up clods. After each plough, weeds and rubbish were removed. Finally, spade was used to prepare plots.

Collection of seed potato tubers: Potato tubers of a local variety (Lal Pakri) were collected from a farmer house located nearby the Bangladesh Agricultural University.

Treatments, design and layout of the experiment: The experiment was laid out in the Randomized Complete Block Design (RCBD), with three replications. Distance between the blocks was $1 \mathrm{~m}$ and between the plots was $0.5 \mathrm{~m}$. The size of unit plot was $(1 \mathrm{~m} \mathrm{X} 1 \mathrm{~m})$ (Figure 1). A total of 10 treatments were used viz. $\mathrm{T}_{1}$ (Control with no spray), $\mathrm{T}_{2}$ (Control with fungicide spray), $\mathrm{T}_{3}$ (Compost tea or extract as foliar spray), $\mathrm{T}_{4}$ (Compost tea or extract as soil drenching), $\mathrm{T}_{5}$ (Poultry litter extract as soil drenching), $\mathrm{T}_{6}$ (Compost as soil application), $\mathrm{T}_{7}$ (Poultry litter (soil application), $\mathrm{T}_{8}$ ( Biopesticide as soil application), $\mathrm{T}_{9}$ (BAU-Biofungicide as foliar spray) and $\mathrm{T}_{10}$ (Mustard Oil Cake as soil application) 


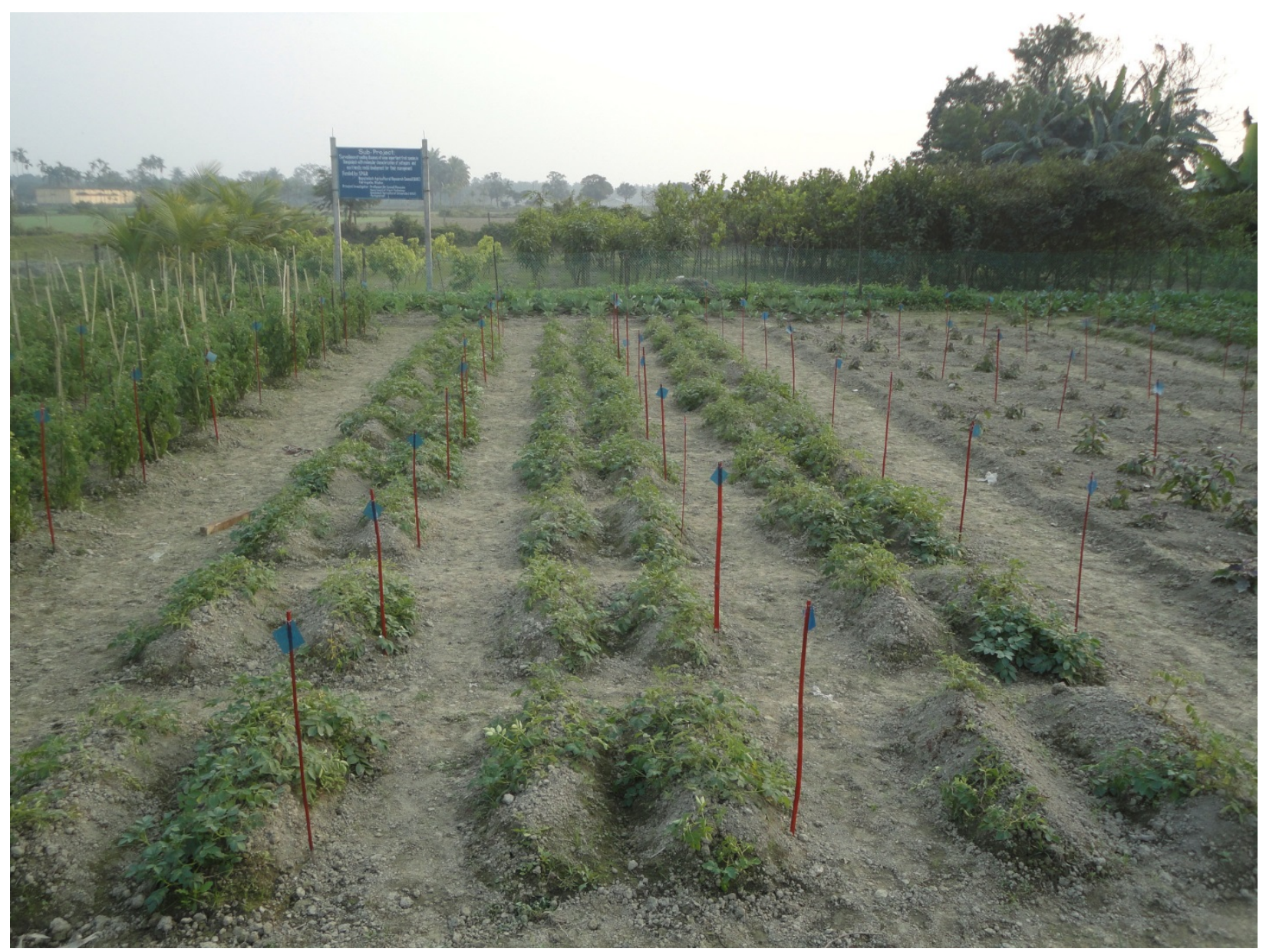

Figure 1. Field view showing the lay out of the experiment following Randomized Complete Block Design (RCBD) with three replications

\subsection{Soil Application of Compost, Poultry Litter, IPM Lab Biopesticide and Mustard Oil Cake as Treatment}

Compost, poultry litter, IPM Lab Biopesticide and Mustard oil cake were applied to the soil of the respective plot at least seven days before final land preparation @ 10 ton/ha, 10 ton/ha, $64 \mathrm{~kg} / \mathrm{ha}$ and 3.0 ton/ha, respectively.

\subsection{Planting of Potato Tubers and Intercultural Operation}

Potato tubers were planted in the plots in two rows at $30 \mathrm{~cm}$ distance on November 11, 2011 using six tubers per row. After planting, gap filling was done in case of any germination failure within a week. General field sanitation was maintained throughout the growing period. Water was applied to the plots in between the two rows.

\subsection{Preparation and Application of Compost Tea and Poultry Litter Extract}

Compost teas or extracts were prepared by mixing compost with tap water at a ratio $1: 5(\mathrm{w} / \mathrm{v})$ followed by fermentation for at least one week. A cup of molasses was added in the mixture during fermentation to enhance the microbial growth in the compost tea. Then it was stirred once every day and allowed to ferment outdoors around at $25^{\circ} \mathrm{C}$. After 7 days, the solution was filtered through cheese cloth and diluted (1:1). Then the prepared compost tea was applied with ordinary sprayers. Poultry litter extracts were prepared similarly for soil drenching.

Foliar spray: Both compost tea and poultry litter extract were then sprayed on the foliage with a sprayer at 15 days interval to the assigned plots @ 1000 L/ha.

Soil drenching: Both compost tea and poultry litter extract were drenched at the base of the plant @ $1 \mathrm{~L} / \mathrm{m}^{2}$ i.e. 10, 000L/ha.

\subsection{Preparation and Application of BAU-Biofungicide}

BAU- Biofungicide was collected from Eco-friendly Plant Disease Management Lab, Department of Plant 
Pathology, Bangladesh Agricultural University, Mymensingh. BAU-Biofungicide was prepared by mixing $20 \mathrm{~g}$ with $1 \mathrm{~L}$ water at a final concentration of $2 \%$ taken in a beaker and mixed with a stirrer. Then it was sieved with cheese cloth and 2-3 drops Tween-20 was added to it. Then the prepared BAU-Biofungicide was sprayed at 2\% concentration@1000 L/ha. The first spray was given 30 days after transplanting (DAT).

\subsection{Identification of Rhizoctonia Stem Canker in the Experimental Field}

The disease was identified in the field based on the symptoms as described previously by Wharton et al., 2007. The per cent incidence of Rhizoctonia stem canker in potato was calculated at 40 and 80 days after planting using the following formula:

$$
\begin{aligned}
& \% \text { Rhizoctonia } \text { stem canker incidence }=\frac{\text { No. of stem canker infected plants per plot }}{\text { Total no. of plants per plot }} \times 100 \\
& 2.7 \text { Isolation and Identification of the Stem Canker Pathogen, } \text { R. solani }
\end{aligned}
$$

The infected stem portion of the collected diseased plants were cut into small pieces and were surface sterilized by dipping in 10\% bleach for 1 minute and then rinsed three times in sterile water. The plant parts were then placed on moist blotter paper in Petridishes with sterile forceps and incubated at $22 \pm 2^{\circ} \mathrm{C}$ for $7-10$ days to allow the growth of pathogen. The pathogen was then transferred into the PDA plates for purification. Then the pathogen was identified under compound microscope following the key out-lined by Alexopoulos (1961) and Ingram and Williams (1971). The organisms were photographed using a compound (Leica) microscope with photographic attachments.

\subsection{Data Collection and Analysis}

The data were collected on the various growth and yield parameters of potato at the time of harvesting. The data were analyzed statistically using analysis of variance to find out the variations resulting from experimental treatments and the treatment means were compared by DMRT (Duncan's Multiple Range Test).

\subsection{Cost-Benefit Analysis and Benefit Cost Ratio (BCR)}

The cost-benefit analysis was done based on gross returns and cost of each treatment to compare the profitability among the treatments. The gross return, gross margin and gross margin over control under each treatment were calculated as follows:

Gross return $(\mathrm{TK} / \mathrm{ha})=$ Fruit Yield $(\mathrm{kg} / \mathrm{ha}) \times$ Price $(\mathrm{TK} / \mathrm{kg})$

Gross margin $(\mathrm{TK} / \mathrm{ha})=$ Gross return $(\mathrm{TK} / \mathrm{ha})$ - Cost of the treatment $(\mathrm{TK} / \mathrm{ha})$

Gross margin over control $(\mathrm{TK} / \mathrm{ha})=$ Gross return under each treatment $(\mathrm{TK} / \mathrm{ha})$ - Gross return under control (TK/ha)

The BCR was calculated by slight modification of the formula of DAS (Anonymous, 1996/97) as used by Rahman (1998) is shown below:

$$
\mathrm{BCR}=\frac{\text { Yield of treated plot }- \text { Yield of control plot }}{\text { Cost of treatments }} \times \text { Price of product }
$$

\section{Results}

\subsection{Identification of Stem Canker and Its Pathogen, R. solani}

The symptoms of the disease are found on both above- and below-ground portions of the plant. Although black scurf is the most conspicuous sign of Rhizoctonia disease, the symptoms appeared as killing of potato sprout with lesions on the tip with poor and uneven stands with weakened plants. Mature red to brown lesions resulting canker symptoms characterized by rough, brown craters, cracks or both. Late season damage to plants is a direct result of cankers on stolons and stem causing interruption of starch translocation. These results in small, green tubers, called aerial tubers, forming on the stem above the soil (Figure 2A). Potato stands may also be mistaken for seed tuber decay caused by Fusarium or soft rot bacteria unless plants are dug out and examined. The pathogen was isolated from the diseased plant parts and was identified based on creamy white color mycelial growth with numerous sclerotia (Figure 2B) and hyphal branching with characteristic septation (Figure 2C). 
A

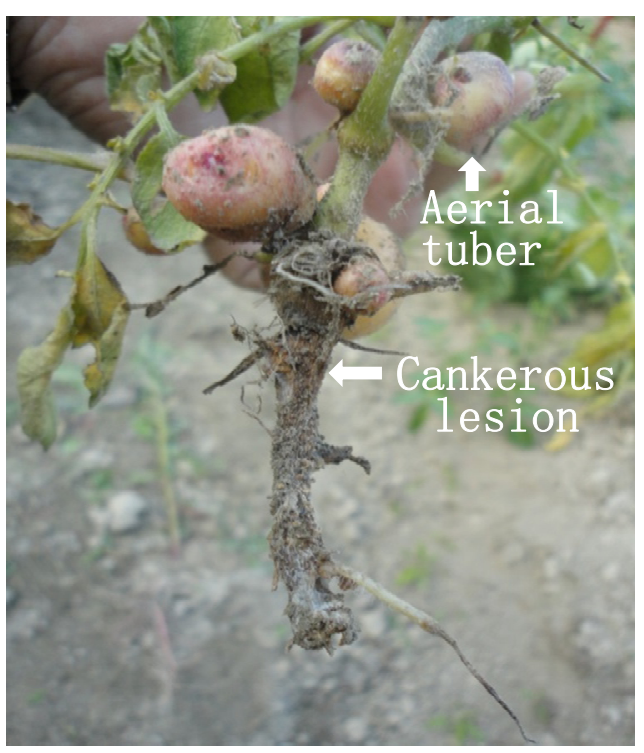

B

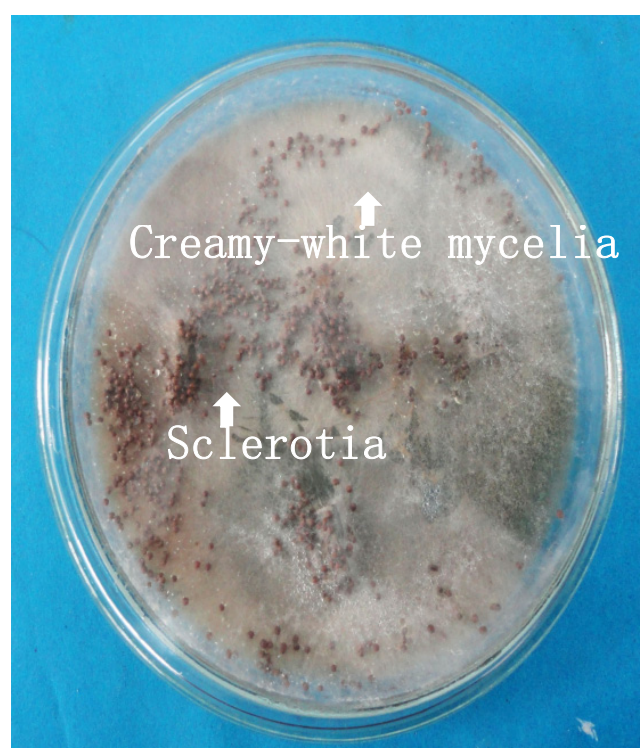

C

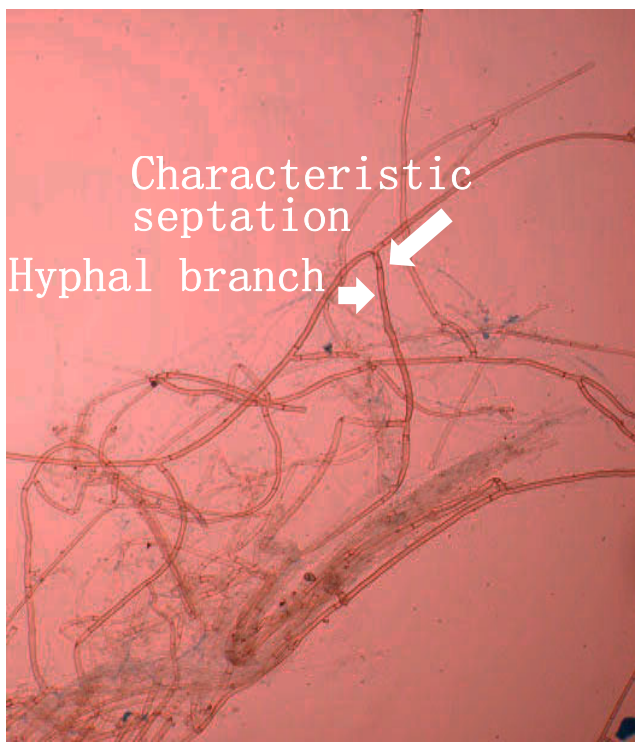

Figure 2 Symptoms of Rhizoctonia stem canker of potato with canker lesions on the stem base and aerial tubers (A), a pure culture of the organisms Rhizoctonia solani with creamy white mycelia and brown color sclerotia (B) and microscopic view of Rhizoctonia solani with hyphal branching and characteristic septa (C)

\subsection{Effect of Compost Tea and Poultry Litter Extract on Stem Canker Incidence}

The application of compost and poultry were reported to be found effective in controlling many soil -borne pathogens of various crop plants. Here in the present study we observed a significant effect of some organic and chemical treatments on the incidence of stem canker of potato as compared to control. The results evidently showed that the significantly lowest stem canker incidence was recorded in $\mathrm{T}_{8}$ (Soil application of IPM Lab Biopesticde) followed by $T_{2}$ (Foliar spray of Ridomil), $T_{3}$ (Foliar spray of compost tea) and $T_{9}$ (Foliar spray of BAU-Biofungicide) and the highest stem canker incidence was recorded in control treatment $\left(\mathrm{T}_{1}\right)$ (Table 1). Application of compost tea and poultry litter extract as soil drenching were also found effective as compared to untreated control in reducing the incidence of stem canker. All other treatments used in this study as positive control showed significantly lower incidence as compared to untreated control $\left(\mathrm{T}_{1}\right)$. 
Table1. Effect of compost tea and poultry litter extract on the incidence of Rhizoctonia stem canker of potato

\begin{tabular}{ll}
\hline Treatments & $\%$ Stem canker infected plant \\
\hline T1 & $25.00 \mathrm{a}$ \\
T2 & $4.79 \mathrm{e}$ \\
T3 & $5.70 \mathrm{de}$ \\
T4 & $10.46 \mathrm{c}$ \\
T5 & $14.09 \mathrm{~b}$ \\
T6 & $15.78 \mathrm{~b}$ \\
T7 & $8.70 \mathrm{~cd}$ \\
T8 & $3.56 \mathrm{e}$ \\
T9 & $4.56 \mathrm{e}$ \\
T10 & $16.43 \mathrm{~b}$ \\
LSD & 3.042 \\
Level of significance & $* *$
\end{tabular}

$\mathrm{T}_{1}$ (Control with no spray), $\mathrm{T}_{2}$ (Control with Ridomil spray), $\mathrm{T}_{3}$ (Compost tea or extract as foliar spray), $\mathrm{T}_{4}$ (Compost tea or extract as soil drenching), $\mathrm{T}_{5}$ (Poultry litter extract as soil drenching), $\mathrm{T}_{6}$ (Compost as soil application), $\mathrm{T}_{7}$ (Poultry litter (soil application), $\mathrm{T}_{8}$ ( Biopesticide as soil application), $\mathrm{T}_{9}$ (BAU-Biofungicide as foliar spray) and $\mathrm{T}_{10}$ ( Mustard Oil Cake as soil application).

** Means with the same letter in the column do not differ significantly at $1 \%$ level of probability. Data represent the averages of 40 and 80 days after planting.

\subsection{Compost Tea and Poultry Litter Extract Enhance the Growth and Yield Parameters of Potato}

To explain the effect of different treatments on growth and yield by reducing the stem canker incidence, the data were taken on growth and yield parameters of potato against each treatment and were analyzed. Significant effects of the treatments were observed on the plant height and yield except number of plant raised per tuber (Table 2). The results showed that all the treatments resulting comparatively higher plant height, number of plants and yield as compared to control. However, foliar application of compost tea, soil application of compost and poultry litter showed better performance in increasing the plant height and yield as compared to all other treatments (Figure 3).

Table 2. Effects of compost tea and poultry litter extract on the growth and yield parameters of potato

\begin{tabular}{lllll}
\hline Treatments & Plant height $(\mathrm{cm})$ & Number of plants & Yield per plot $(\mathrm{Kg})$ & Yield per ha $(\mathrm{t})$ \\
\hline T1 & $21.77 \mathrm{abc}$ & 3.61 & $1.22 \mathrm{~d}$ & $12.20 \mathrm{f}$ \\
T2 & $21.06 \mathrm{bc}$ & 2.91 & $2.24 \mathrm{abc}$ & $22.40 \mathrm{bcd}$ \\
T3 & $23.50 \mathrm{abc}$ & 3.80 & $2.85 \mathrm{a}$ & $28.50 \mathrm{a}$ \\
T4 & $19.63 \mathrm{~cd}$ & 3.89 & $1.74 \mathrm{~cd}$ & $17.40 \mathrm{e}$ \\
T5 & $22.00 \mathrm{abc}$ & 3.76 & $2.08 \mathrm{bc}$ & $20.80 \mathrm{cde}$ \\
T6 & $15.87 \mathrm{~d}$ & 4.04 & $2.55 \mathrm{ab}$ & $25.50 \mathrm{abc}$ \\
T7 & $24.90 \mathrm{ab}$ & 3.26 & $2.20 \mathrm{abc}$ & $22.00 \mathrm{~b}-\mathrm{e}$ \\
T8 & $21.46 \mathrm{abc}$ & 3.72 & $1.80 \mathrm{~cd}$ & $18.00 \mathrm{de}$ \\
T9 & $20.33 \mathrm{c}$ & 3.44 & $2.30 \mathrm{abc}$ & $23.00 \mathrm{bc}$ \\
T10 & $25.57 \mathrm{a}$ & 3.25 & $2.61 \mathrm{ab}$ & $26.43 \mathrm{ab}$ \\
LSD & 3.832 & - & 0.606 & 4.470 \\
Level of significance & $* *$ & NS & $* *$ & $* *$
\end{tabular}

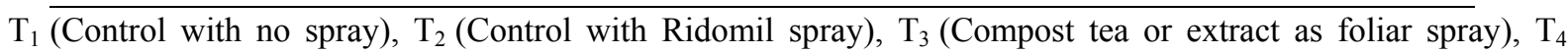
(Compost tea or extract as soil drenching), $\mathrm{T}_{5}$ (Poultry litter extract as soil drenching), $\mathrm{T}_{6}$ (Compost as soil application), $\mathrm{T}_{7}$ (Poultry litter (soil application), $\mathrm{T}_{8}$ ( IPm Lab Biopesticide as soil application), $\mathrm{T}_{9}$ (BAU-Biofungicide as foliar spray) and $\mathrm{T}_{10}$ ( Mustard Oil Cake as soil application).

** Means with the same letter in the column do not differ significantly at $1 \%$ level of probability NS-Not significant. 
A

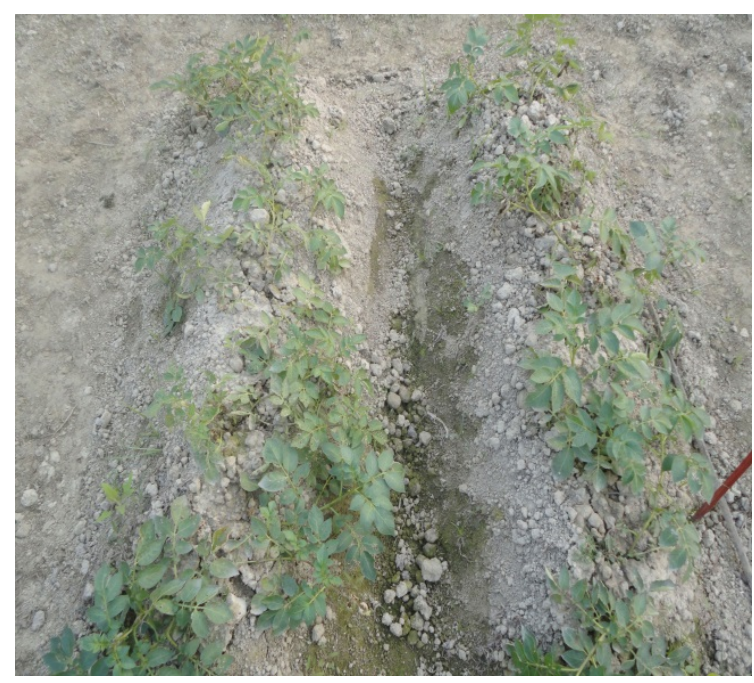

$\mathrm{C}$

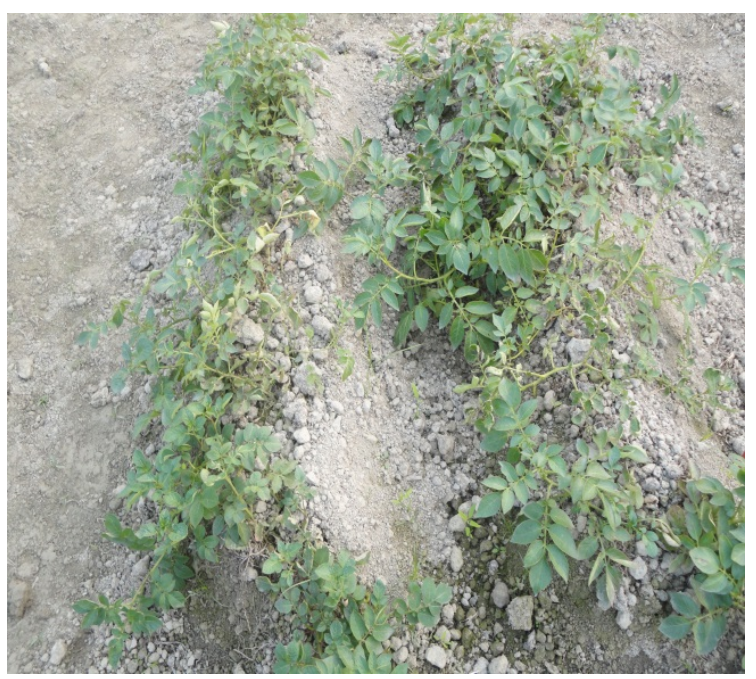

B

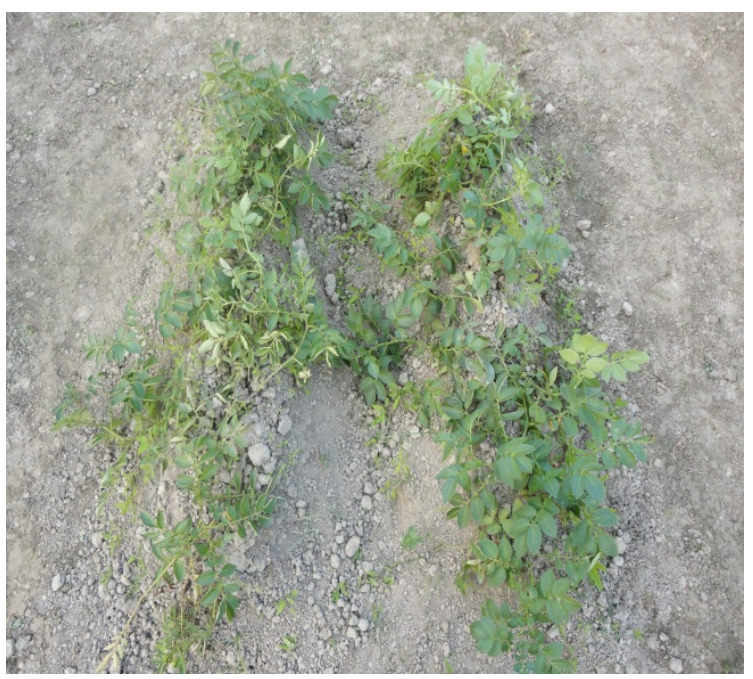

$\mathrm{D}$

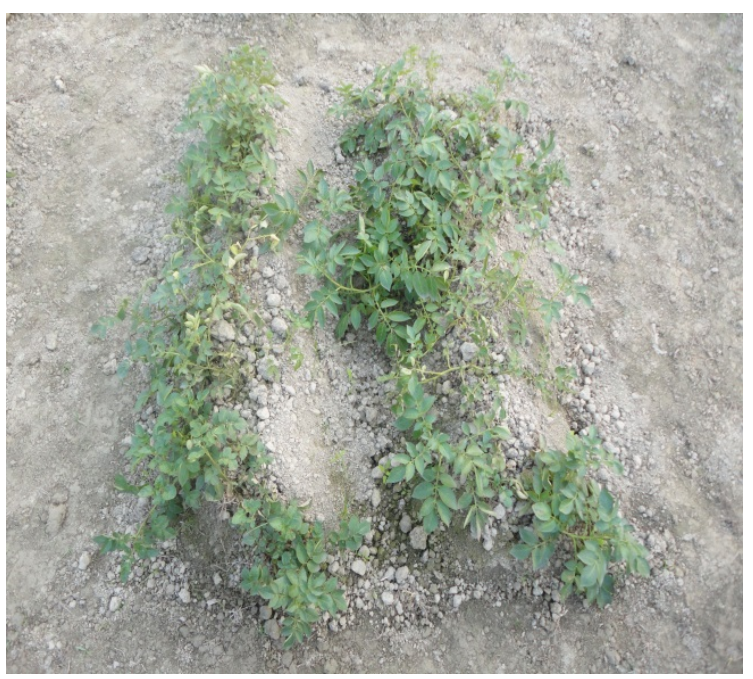

Figure 3. Experimental plots showing the effects of different treatments on the growth of potato plants. Control plot (A), plots received the compost tea as foliar spray (B), soil application of compost (B), and poultry litter extract as soil drenching (D)

\subsection{Analyses of Benefit Cost Ratio (BCR)}

To test the economic feasibility of using compost tea as an alternative means of controlling stem canker of potato, BCR were determined for each treatment. The results showed that foliar application of compost tea yielded the highest BCR (65.20) and gross margin over control (44.92\%) followed by T8 (Soil application of IPM Lab Biopesticide) with BCR 54.38 and gross margin over control (31.82) (Table 3 and Figure 4). The treatment T2 (Foliar spray of Ridomil) and T9 (Foliar spray of BAU-Biofungicide) resulted 35.31 and 38.88 BCR and 35.48 and $46.3 \%$ gorss margin over control, respectively as compared to untreated control. These treatments also showed higher BCR because of low treatment cost as shown in Table 3. The results indicated that an investment of Tk. 1.00 may lead to a profit up to Tk. 65.20 by foliar application of compost tea and may lead to a profit of Tk. 54.38 in case of soil application of IPM Lab Biopesticide which were the maximum profit in the present study. 
Table 3. Cost-benefit analysis of different treatments used in controlling stem canker of potato in the field

\begin{tabular}{llllllll}
\hline Treatment & $\begin{array}{l}\text { Average } \\
\text { yield } \\
\text { (t/ha) }\end{array}$ & $\begin{array}{l}\text { Gross } \\
\text { return } \\
\text { (Tk/ ha) }\end{array}$ & $\begin{array}{l}\text { Production cost } \\
\text { (Tk/ha) }\end{array}$ & $\begin{array}{l}\text { Total cost of } \\
\text { treatment }\end{array}$ & $\begin{array}{l}\text { Gross } \\
\text { margin }\end{array}$ & $\begin{array}{l}\text { Gross margin } \\
\text { over control }\end{array}$ & BCR \\
\hline T1 & 12.2 & $2,19,600$ & & - & $2,19,600$ & - & \\
T2 & 22.4 & $3,45,600$ & & 5200 & $3,40,400$ & $1,26,000$ & 35.31 \\
T3 & 28.5 & $4,03,200$ & & 4500 & $3,98,700$ & $1,83,600$ & 65.20 \\
T4 & 17.4 & $5,13,000$ & & 20,000 & $4,93,000$ & $2,93,400$ & 4.68 \\
T5 & 20.8 & $3,74,400$ & 1,00000 & 60,000 & $3,14,400$ & $1,54,800$ & 2.58 \\
T6 & 25.5 & $4,59,000$ & & 50,000 & $4,09,000$ & $2,39,400$ & 4.79 \\
T7 & 22.0 & $3,90,000$ & & 150,000 & $2,40,000$ & $1,70,400$ & 1.18 \\
T8 & 18.0 & $3,24,000$ & & 1920 & $3,22,080$ & $1,02,480$ & 54.38 \\
T9 & 23.0 & $4,14,000$ & & 5000 & $4,09,000$ & $1,94,400$ & 38.88 \\
T10 & 26.1 & $4,69,800$ & & 90,000 & $3,79,800$ & $2,50,200$ & 2.78 \\
\hline
\end{tabular}

Potato: Tk 18/kg Compost: Tk 5/kg, Poultry litter: Tk 15/kg BAU Biofungicide: Tk 100/kg IPM Lab Biopesticide Tk $30 \mathrm{~kg} / \mathrm{ha}$ and Mustard oil cake Tk. 30/kg.

$\mathrm{T}_{1}$ (Control with no spray), $\mathrm{T}_{2}$ (Control with Ridomil spray), $\mathrm{T}_{3}$ (Compost tea or extract as foliar spray), $\mathrm{T}_{4}$ (Compost tea or extract as soil drenching), $\mathrm{T}_{5}$ (Poultry litter extract as soil drenching), $\mathrm{T}_{6}$ (Compost as soil application), $\mathrm{T}_{7}$ (Poultry litter (soil application), $\mathrm{T}_{8}$ (Biopesticide as soil application), $\mathrm{T}_{9}$ (BAU-Biofungicide as foliar spray) and $\mathrm{T}_{10}$ ( Mustard Oil Cake as soil application).

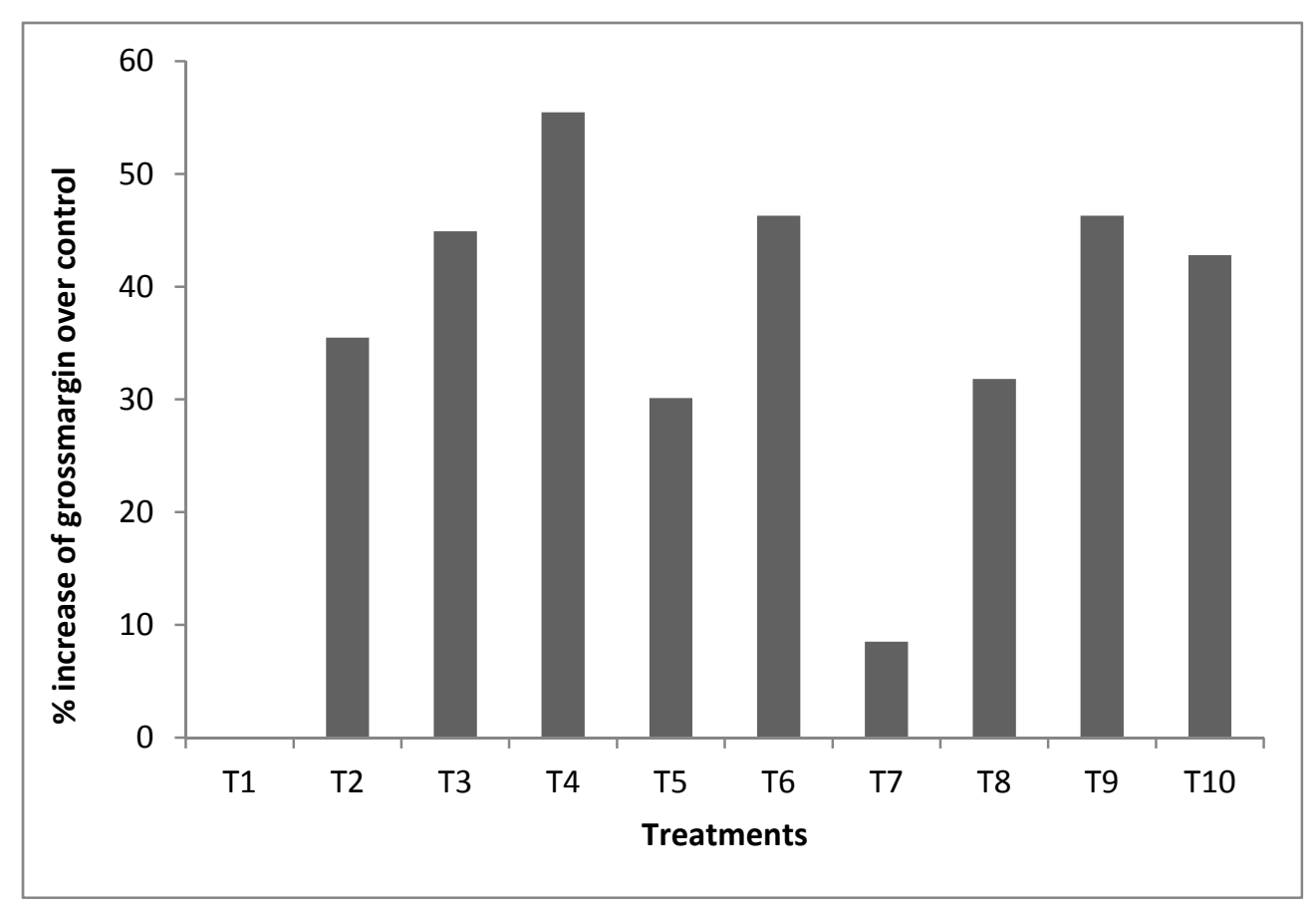

Figure 4. Percent increase of gross margin for each treatment over control. $T_{1}$ (Control with no spray), $T_{2}$ (Control with Ridomil spray), $\mathrm{T}_{3}$ (Compost tea or extract as foliar spray), $\mathrm{T}_{4}$ (Compost tea or extract as soil drenching), $\mathrm{T}_{5}$ (Poultry litter extract as soil drenching), $\mathrm{T}_{6}$ (Compost as soil application), $\mathrm{T}_{7}$ (Poultry litter (soil application), $\mathrm{T}_{8}$

( Biopesticide as soil application), $\mathrm{T}_{9}$ (BAU-Biofungicide as foliar spray) and $\mathrm{T}_{10}$ ( Mustard Oil Cake as soil application) 


\section{Discussion}

Stem canker caused by the fungus Rhizoctonia solan is difficult to control because of the soil-borne nature of its pathogen. But combined approaches which include cultural and crop protection strategies may limit its severity. A number of chemical products have been found effective in controlling the disease but unfortunately these products exerted some adverse effects on the emergence of the tubers (Wharton et al., 2007). Report revealed that bio-fumigation reduces the Rhizoctonia incidence in the field. In the present study, we evaluated the performance of some organic components as an alternative means in controlling stem canker of potato. We found that foliar application of compost tea and soil drenching of poultry litter extract reduced the incidence of stem canker disease of potato in the field as compared to the control treatment. Although foliar application of Ridomil performed best in reducing the incidence of stem cankers. However, Ridomil did not perform better in increasing the growth and yield parameters of potato as compared to compost, compost tea and mustard oil cake. All other treatments used in this study as positive control showed significantly lower incidence as compared to untreated control $\left(T_{1}\right)$ suggesting the use of feasibility of these organic components in controlling stem canker of potato. Organic manures has been reported to have some positive impact in reducing the incidence and severity of many diseases of some economically important crop plants (Aryantha et al., 2000; Nelson et al., 2002; Shaikh \& Ghaffar, 2004; Ben Jenana et al., 2009; Saadi et al., 2010; Pane et al., 2011; Ahmed et al., 2012). Several mechanisms were reported to be involved in the process how the organic manures reduce these soil-borne pathogens. Firstly, compost derived beneficial microbes compete for nutrients with plant pathogens in the rhizosphere (De Brito et al., 1995; Hoitink \& Boehm, 1999). Secondly, production of antibiotic compounds by beneficial microorganisms may inhibit the various plant pathogens, a process known as antibiosis (Hoitink et al., 1996), the thirdly Parasitism and predation of soil inhabiting pathogens by compost inhabiting beneficial microorganisms (Hoitink \& Boehm, 1999) and the final mechanism of biocontrol involves in inducing of systemic resistance in plants by microorganisms from composts or soils (Zhang et al., 1996). Hoitink and Grebus (1994) also reported the pathogen suppression by compost includes inhibition of pathogen growth, pathogen survival and reduction of infection (increased host resistance or competition for infection sites of the host. Competition for food takes place through both direct antagonism and production of antibiotics were also reported (Chen \& Inbar, 1993; Hoitink \& Fahy, 1986).

The foliar application of compost tea reduces the incidence of the stem canker possibly by providing some micronutrients to plants and may also by triggering some signalling pathways in plants. One of the leading explanations is the induction of systemic acquired resistance (SAR). Zhang et al. (1998) observed SAR in cucumber and Arabidopsis by using compost and compost extracts. Furthermore, compost tea may enrich the beneficial microbial community in the plant surfaces which in turn compete with other foliar pathogens and reduced their growth and development on the plant surfaces. The antifungal activity of compost extract which may inhibit the growth of other foliar pathogens and increased crop vigor were also reported (El-Masry et al., 2002; Kerkeni et al., 2007). Organic teas reported to increase vigour and hardness on the plant by providing both micronutrients and the organic chelating agents (Merrill et al., 1998). Foliar fertilization is also reported to increase the production of root exudates, which stimulates biological activity in rhizosphere (Kupper, 2000). Ingham (2001) explained that the life in the soil and on plant surfaces will increase and broadening of species diversity of the communities when compost extracts correctly prepared and applied.

The increased yield and protein content were reported in potato when plants were grown in the soil applied composted animal manure (Srikumar \& Ockerman, 1990) and composted plant material added to soil was also observed for increasing yield in sweet potato (Ipomoea batatus). (Preston, 1990, Floyd et al., 1988). Significant increase in tomato yield was also reported with compost amendment (Cheuk, 2005). Besides, significant yield increase in eggplant was observed as a result of disease suppressiveness and growth promoting effect of compost (Paplomatas, 2005). Trichoderma lead to increase nutrient availability and uptake results stronger nutrient uptake by plant and thereby develops the root system which makes better support for shoot growth and development. These parameters for plant vigor are important to overcome biotic and/or abiotic stresses and to increase in plant productivity and yields (Azarmi et al., 2011). The higher yield obtained from the plants grown in the plots received compost tea, poultry litter extract, IPM lab Biopesticide and BAU-Biofungicide in our study might be due to the beneficial activity of Trichoderma along with other beneficial microbes and the nutrients present in these organic components.

\section{Conclusion}

Foliar spray of compost tea may be used as an alternative environment friendly means of plant disease control to increase crop growth and yield with maximum profit. Further investigations are required to draw any conclusion on the use of compost tea and poultry litter extract in controlling soil-borne diseases. However, Feasibility of 
using compost tea and poultry litter extract in plant disease control need to be re-evaluated considering the human health and ethical issues as compared to other existing formulated biopesticides or biofungicides before being released as a technology at farmers' level.

\section{Acknowledgements}

This research work was supported partly by the grants of Bangladesh University Grants Commission, Bangladesh Agricultural University Research System (BAURES) to Dr. Md. Rashidul Islam and by USDA research grants to Dr. M. Bahadur Meah, IPM Lab., Department of Plant Pathology, Bangladesh Agricultural University, Mymensingh, Bangladesh.

\section{References}

Agrios, G. N. ( 2005). Plant Pathology. 4th Edition. Academic press, London, New York; USA.

Ahmed, S., Zaman, N., \& Khan, S. N. (2012). Evaluation of manuring practices on root rot disease and agronomic characters of Arachis hypogeae L. Afr J Biotechnol, 11(5), 1119-22.

Alexpoulos. (1961). Major Diseases of Potato, tomato, laddis finger and country bean and their control (In Bengali). BARC, Dhaka: Bangla Press.

Anonymoius. (1996/1997). Field demonstrated on Soil fertilizer. General Guidelines. DAE (FSW) SFFP. 17-18.

Aryantha, I. P., Cross, R., \& Guest, D. I. (2000) Suppression of Phytophthora cinnamomi in Potting Mixes amended with uncomposted and composted animal manures. Phytopathology, 90(7), $775-82$. http://dx.doi.org/10.1094/PHYTO.2000.90.7.775

Azarmi, R., Hajieghrari, B., \& Giglou, A. (2011). Effect of Trichoderma isolates on tomato seedling growth response and nutrient uptake. Afr. J. Biotechnol, 10(31), 5850-5855.

Bains, P. S., Bennypaul, H. S., Lynch, D. R., Kawchuk, L. M., \& Schaupmeyer, C. A. (2002). Rhizoctonia disease of potatoes (Rhizoctonia solani): fungicidal efficacy and cultivar susceptibility. Am J Potato Res, 79(2), 99-106. http://dx.doi.org/10.1007/BF02881518

Banville, G. J. (1989). Yield losses and damage to potato plants caused by Rhizoctonia solani Kuhn. Am Potato J, 66, 821-34. http://dx.doi.org/10.1007/BF02853963

Ben Jenana, R. K., Haouala, R., \& Triki, M. A. (2009). Compost, compost extract and bacterial suppressive action on Pythium aphanidermatum in tomato. Pak J Bot, 41(1), 315-27.

Carling, D. E, Leiner, R. H., \& Westphale, P. C. (1989). Symptoms, signs and yield reduction associated with Rhizoctonia disease of potato induced by tuberborne inoculum of Rhizoctonia solani AG-3. A Potato J, 66, 693-701. http://dx.doi.org/10.1007/BF02896825

Chen, W., Hoitnik, H. A. J., \& Schmitthenner, A. F. (1988). Factors affecting the suppression of Pythium damping off in container media amended with compost. Phytopatology, $77,755$. http://dx.doi.org/10.1094/Phyto-77-755

Chen, Y., \& Inbar, U. (1993). Chemical and spectroscopical analysis of organic matter transformation during composting in relation to compost maturity. In H. A. J. Hoitnik \& H. M. Keener (Eds.), Science and engineering of composting: Design, environmental nicrobiological and utilization aspects (pp.500-600). Worthington, $\mathrm{OH}$ : Renaissance Publications.

Cheuk, K. (2005). Disease suppression on greenhouse tomatoes using plant waste compost. J. Environ. Sci. and Health, Part B, Pesticides, Food Contaminants, and Agricultural Wastes, 40(3), 449-461. http://dx.doi.org/10.1081/PFC-200047582

De Brito, A., Gagne, S., \& Antoun, H. (1995). Effect of compost on rhizosphere microflora of the tomato and on the incidence of plant growth-promoting rhizobacteria. Appl Environ Microbiol, 61, 194-99.

Diver, S. (1998). Compost Teas for Plant Disease Control. National Center for Appropriate Technology, U.S. Department of Agriculture. ATTRA publication, May 1998.

Eklas Hamid, E., Himeidan, Y. E., \& El-Hassan, S. M. (2006). Cultural practices for the management of Rhizoctonia disease in potato. J King Saud Univ, 18(2), 141-48.

EL-Bakali, A. M., \& Martin, M. P. (2006). Black scurf of potato. Mycologist, 20, $130-132$. http://dx.doi.org/10.1016/j.mycol.2006.03.006 
El-Masry, M. H, Khalil, A. I, Hassouna, M. S., \& Ibrahim, H. A. H. (2002). In situ and in vitro suppressive effect of agricultural composts and their water extracts on some phytopathogenic fungi. World J Microbiol Biotechnol, 18, 551-58. http://dx.doi.org/10.1023/A:1016302729218

Errampalli, D., \& Johnston, H. W. (2001). Control of tuber-borne black scurf (Rhizoctonia solani and common scab (Streptomyce scabies) of potato with combination of sodium hypochlorite and thiophanate-methyl pre-planting seed tuber treatment. Canadian J Plant Pathol, 23, 68-77. http://dx.doi.org/10.1080/07060660109506911

Floyd, C. N. D., Sousa, E. J., \& Lefroy, R. D. B. (1988). Soil fertility and sweet potato production on volcanic ash soils in the highlands of Papua New Guinea. Field Crops Res, 19, 1. http://dx.doi.org/10.1016/0378-4290(88)90030-5

Hoitink, H. A. J., \& Grebus, M. E. (1994). Status of biological control of plant diseases with composts. Compost Sci Util, 2(2), 6-12. http://dx.doi.org/10.1146/annurev.phyto.37.1.427

Hoitink, H. A. J., Stone, A. G., \& Grebus, M. E. (1996). Suppression of plant diseases by composts. In M. De Bertoldi, P. Sequi, B. Lemmes, \& T. Papi (Eds.), The Science of Composting, 1, 373- 381. Blackie Academic \& Professional, Glasgow. http://dx.doi.org/10.1146/annurev.py.24.090186.000521

Hoitink, H. A. J., \& Boehm, M. J. (1999). Biocontrol within the context of soil microbial communities: A substrate-dependent phenomenon. Ann Rev Phytopathol, 37, 427-46.

Hoitnik, H. A. J., \& Fahy, P. C. (1986). Basis for the control of soilborne plant pathogens with composts. Annual Review of phytopatology, 24, 93-114.

Hoitnik, H. A. J., Inbar, R., \& Boehm, M. J. (1993). Compost can suppress soil-borne diseases in container media. Am. Nurserym, 178(16), 91.

Hossain, I. (2011). BAU-Biofungicide: Unique Eco-friendly Means and New Dimension of Plant Disease Control in Bangladesh. Department of Plant Pathology, Bangladesh Agricultural University, Mymensingh.

Ingham, R. E. (2001). Composting Tea Brewing manual (2nd ed.). Oregon: Soil Foodweb Inc.

Ingram, D. S., \& Williams, P. H. (1991). In Advances in Plant Pathology (Vol. 5, pp.55-118). London and New York: Academic Press.

Jager, G., Velvis, H., Lamers, J. G, Mulder, A., \& Roosjen, J. (1991). Control of Rhizoctonia solani in potato by biological, chemical and integrated measures. Potato Res, 34, 269-84. http://dx.doi.org/10.1007/BF02360500

Jager, M. J., Hide, G. A., Van Den Boogert, P. H. J. F., Termorshuizen, A. J., \& Van Baarlen, P. (1996). Pathology and control of soil borne fungul pathogens of potato. Potato Res, 39, 437-69. http://dx.doi.org/10.1007/BF02357949

Kerkeni, A., Daami-Remadi M, Tarchoun, N., \& Khedher, M. B. (2007). In vitro assessment of the antifungal activity of several compost extracts obtained from composted animal manure mixtures. International. J Agric Res, 2(9), 786-94.

Kupper, G. (2000). Foliar fertilization current topic. National Center for Appropriate Technology, U.S. Department of Agriculture.

Little, G. R., Marquinez, \& Cooke, L. R. (1998). The response of twelve potato cultivars to infection with Rhizoctonia solani. Ann App Biol, 122, 88-89.

Merill, R., Hoberecht, K., \& McKeon, J. (1998). Organic teas from compost and Manures. Organic Farming Research Foundation. P.O. Box 440 Santa Cruz.

Nelson, E. B., \& Hoitink, H. A. J. (1982). Factors effecting suppression of Rhizoctonia solani in container media. Phytopathology, 72, 275-279.

Nelson, E. B., \& Boehm, M. J. (2002). Microbial mechanics of composted induced disease suppression. Part II. Biocycle, 43(7), 45-47.

Pane, C., Spaccini, R., Piccolo, A., Scala, F., \& Bonanomi, G. (2011). Compost amendments enhance peat suppressiveness to Pythium ultimum, Rhizoctonia solani and Sclerotinia minor. Biological Control, 56(2), 115-24. http://dx.doi.org/10.1016/j.biocontrol.2010.10.002

Papavizas, G. C. (1985). Trichoderma and Gliocladium:biology.ecology, and potential for biocontrol. Ann. Rev. Phytupatol, 23, 23. http://dx.doi.org/10.1146/annurev.py.23.090185.000323 
Paplomatas, J. (2005). Evaluation of compost amendments for suppressiveness against Verticillium wilt of eggplant and study of mode of action using a novel Arabidopsis pathosystem. European J. Plant Pathol, 112(2), 183-189. http://dx.doi.org/10.1007/s10658-005-3502-z

Preston, S. R. (1990). Investigation of compost $x$ fertilizer interactions in sweet potato grown on volcanic ash soils in the highlands of Papua New Guinea. Trop.

Rahman, S. (1998). Efficacy of some selected fungicides and plant extract in controlling leaf blight of wheat. MS. thesis. Department of plant Pathology, BAU, Mymensingh.

Rich, J. R., \& Hodge, C. H. (1993). Utilization of blue crab scrap compost to suppress Meloidogine javanica on tomato. Nematropica, 23(1), 1.

Saadi, I., Laor, Y., Medina, S., Krassnovsky, A., \& Raviv, M. (2010). Compost suppressiveness against Fusarium oxysporum was not reduced after one-year storage under various moisture and temperature conditions. Soil Biol Biochem, 42(4), 626-34. http://dx.doi.org/10.1016/j.soilbio.2009.12.016

Shaikh, A. H., \& Ghaffar, A. (2004). Effect of poultry manure and sawdust on survival of sclerotia Macrophomina phaseolina in soil. PakJ Bot, 36(2), 425-428.

Srikumar, T. S., \& Ockerman, P. A. (1990). Theeffects of fertilization and manuring on the content of some nutrients in potato (var.provita). Food. Chem., 37, 47. http://dx.doi.org/10.1016/0308-8146(90)90044-5

Tsror, L., Baraka, R., \& Snehb, B. (2001). Biological control of black scurf on potato under organic management. Crop Protect, 20(2), 145-150. http://dx.doi.org/10.1016/S0261-2194(00)00124-1

Tunlid, A., Hoitnik, H. A. J., Low, C., \& White, D. C. (1989). Characterization of bacteria that suppress Rhizoctonia damping off in bark compost media by analysis of fatty acid biomarkers. Appl.Environ.Microbiol, 55(6), 1368.

Voland, R. P., \& Epstain, A. H. (1994). Development of suppressivness to disease caused by Rhizoctonia solani in soils amended with composted and v noncomposted manure. Plant dis., 78(5), 461. http://dx.doi.org/10.1094/PD-78-0461

Wharton, P., Kirk, W., Berry, D., \& Snapp, S. (2007). Rhizoctoni stem canker and black scurf of potato. Extension Bulletin E-2994

Wilson, P. S., Ketola, E. O., Ahvenniemi, P. M., Lehtonen, M. J., \& Valkonen, J. P. T. (2008). Dynamics of soilborne Rhizoctonia solani in the presence of Trichoderma harzianum: effects on stem canker, black scurf and progeny tubers of potato. Plant Pathol, 57(1), 152-61.

Zhang, W., Dick, W. A., \& Hoitink, H. A. J. (1996). Compost induced systemic acquired resistance in cucumber to Pythium root rot and anthracnose. Phytopathology, 86, 1066-70. http://dx.doi.org/10.1094/Phyto-86-1066

Zhang, W., Han, D. Y., Dick, W. A., Davis, K. R., \& Hoitink, H. A. J. (1998). Compost and compost water extract-induced systemic acquired resistance in cucumber and Arabidopsis. Phytopathology, 88, 450-55. http://dx.doi.org/10.1094/PHYTO.1998.88.5.450

\section{Copyrights}

Copyright for this article is retained by the author(s), with first publication rights granted to the journal.

This is an open-access article distributed under the terms and conditions of the Creative Commons Attribution license (http://creativecommons.org/licenses/by/3.0/). 